\title{
Incorporating Knowledge of Legal and Ethical Aspects into Computing Curricula of South African Universities
}

\author{
lan Wayman and Michael Kyobe \\ Department of Information Systems, University of Cape Town, \\ Cape Town, South Africa
}

\section{ianjw1@gmail.com; Michael.kyobe@uct.ac.za \\ Executive Summary}

As students in computing disciplines are introduced to modern information technologies, numerous unethical practices also escalate. With the increase in stringent legislations on use of IT, users of technology could easily be held liable for violation of this legislation. There is however lack of understanding of social aspects of computing, and institutions have not integrated many of these aspects into their curricula. The present study investigates the extent to which legal and ethical issues relating to IT are integrated in the undergraduate curricula in South African Universities. It also examines the factors that impede such integration.

A review of literature on ethics, computing legislation, and curriculum development was conducted. Research questions were formulated and mixed methods consisting of the study of handbooks, a survey, and follow-up interviews were employed to collect data from different universities in South Africa offering computing disciplines.

The main findings suggest low levels of knowledge of especially legal aspects which constrains their incorporation into the curriculum. The process of integration is mainly influenced by departmental policies and politics. Most institutions have, however, integrated legal and ethical aspects as add-ons topics to existing computing curriculum courses as opposed to running separate courses focusing on the subjects. A guide is being developed to facilitate the incorporation of legal content elements into undergraduate computing curricula.

Keywords: Undergraduate, Computing curriculum, Integration of legal and ethical aspects; Universities, South Africa

\section{Introduction}

In recent times universities are experiencing increasing pressure from changes in various areas of their operations. Businesses are increasingly looking for graduates with broader knowledge and practical skills, competition for students is also growing, and students demand more innovative

Material published as part of this publication, either on-line or in print, is copyrighted by the Informing Science Institute. Permission to make digital or paper copy of part or all of these works for personal or classroom use is granted without fee provided that the copies are not made or distributed for profit or commercial advantage AND that copies 1) bear this notice in full and 2) give the full citation on the first page. It is permissible to abstract these works so long as credit is given. To copy in all other cases or to republish or to post on a server or to redistribute to lists requires specific permission and payment of a fee. Contact Publisher@InformingScience.org to request redistribution permission. and flexible approaches to learning (Reid, 1999). Universities therefore have to offer better and more up-to-date curricula in order to remain competitive.

In computing disciplines, students are introduced to modern IT and powerful tools. Numerous unethical practices are being escalated by the widespread adoption of information technology (Sutirtha, 2005). 
Conger and Loch (1995) claim that the lack of a social conscience within the IT profession was a serious short coming. In addition, Artz (1994) contends that most computer professional who develop information systems would face various social or ethical problems, for example those relating to system reliability, quality, and failure (p.17).

In addition to the above concerns, there are increasing demands of new government legislations on IT which impact on computing practices and need to be understood and adhered to by IS practitioners and students. Legal and ethical aspects pertinent to computing are therefore integral parts of the computing curricula at tertiary institutions and have been for some time (ACM/IEEE-CS Joint Curriculum Task Force in Computing Curricula, 1991; Martin \& Yale-Weltz, 1999). However, not many institutions have managed to incorporate these aspects into their computing curricula (Kyobe, Moloi, \& Salie, 2009).

While ACM/IEEE and other bodies have contributed greatly to providing guidance on the integration of social aspects into the computing curricula, and researchers and practitioners have also called for the integration of electronic law into the curricula, institutions are experiencing major challenge in implementing these aspects. This study, therefore, investigates the extent to which legal and ethical issues pertinent to computing are integrated in the undergraduate curricula in South African Universities and the challenges experienced by institutions in this process.

In the following sections a review is conducted of literature on computer ethics, computing legislation and the challenges involved in integrating these in the curricula. Research questions for this study are then formulated and the research methodology is presented. The findings of the current study are presented and discussed in the following section. Finally, conclusions are drawn and future recommendation made.

\section{Literature Review}

\section{Computer Ethics}

The increase in unethical practices resulting from the use of computers and the increase in the stringent legislation governing the use of technologies has made it imperative to integrate these aspects in the students' curricula. With this knowledge, it is anticipated that good practice in computing can be ensured, and students can identify the legal challenges and understand potential liabilities. Ethics is the study of what it means to do the right thing (Baase, 1997). Baase (2007) defines computer ethics as ethical issues faced by the computer professional as part of their job. In an earlier view of computer ethics proposed by Moor (1985), computer ethics is seen as the analysis of the nature and social impact of computer technology and the corresponding formulation and justification of policies for the ethical use of such technology. Moor's definition is adopted in this study, and in the following sections we examine the development of ethical aspects in the computing curriculum.

\section{Can ethics be taught?}

The issue of whether ethics can be taught has been a subject of debates in the past. In an early account by Plato (Plato's Meno), two philosophers debated the issue of whether ethics could be taught. The debate was between Socrates and Meno. Meno thought that virtue could be taught and, in addition, that it was a duty of the teacher to facilitate the excellence of their students. Socrates differed on this and submitted that man obtained his virtue from God. He maintained that the worth of this virtue (the excellence or success of it) was not shaped by people's experiences in life. He reasoned that if it was shaped by experience then people with the same level of education should have the same level of skill. This he argued was not the case as skill levels varied between artisans with the same level of training (Scott, 2006). Cragg (1997) appears to support this posi- 
tion. He argues that students entering universities bring with them a moral fibre that is not changed with the advent of higher education. Those in favour of Cragg's argument maintain that students moral characters are defined during their earlier formative years (Urmson, 1991).

Aristotle and Plato concurred with Meno as they thought that training and education had a positive bearing on virtue and behaviour. Aristotle argued that obtaining a knowledge of virtue was achievable via education (Dillon, 2004). He further contended that education is a key part of man's search for virtue (Finkelberg, 2002). Regardless of this debate, with the escalation of crime committed using IT and the growing stringent government legislation demanding ethical practices and legal compliance by all IT users, it has become imperative that ethical and legal issues be included in the computing curricula and taught in institutions of learning.

However, the process of integrating ethical and legal aspects into the computing curricula has not been that straight forward. Morris (2007) for instance highlights the difficulties in teaching law to non-law students. In the following section, we outline the contribution by the ACM, IEEE and other organisations in introducing social-ethical issues in computing and the challenges involved in integrating these aspects in curricula.

\section{Social-ethical issues in computing curricula}

The need to focus on social impacts of computing was proposed as early as 1978 by the ACM (Association for Computing Machinery). However, the emphasis on Curricula 78 was still on programming (Bogoiavlenski et al., 1997). Later in 1991, Curricula 1991 specifically stated that social and ethical concerns are part of the computing field as illustrated by this quote from Tucker, Barnes, Aiken, Barker, and Bruce (1991):

Undergraduate programs should provide an environment in which students are exposed to the ethical and societal issues associated with the computing field. This includes maintaining currency with recent technological and theoretical developments, upholding general professional standards, and developing an awareness of one's own strengths and limitations as well as those of the discipline itself. (p.58)

The role of professional ethics and social impact within Curricula has been cemented since then as indicated in later Curricula 2001 and Curricula 2005. Computing Curricula 2005 (CC2005), (see Table 1), includes a comparative weighting of the knowledge areas across the degree programs.

Attention is drawn to the entry in Table 1, for "Legal / Profession/ Ethics / Society" where the rating for it is consistent throughout all the computing degree programs. This serves to show that the ACM considers that these aspects of legality, professionalism, and socio-ethical concerns are of importance across all the computing degree programs in CC2005. Many professional accreditation bodies and institution of learning have recognised this mandate and as such included aspects of ethics, social implications and professional practice in their courses. However, the integration of these aspects into the curricula has also presented many challenges for institutions. These are discussed in the following section. 
Table 1: Comparative weight of computing topics across the five kinds of degree program, Computing Curricula 2005: The Overview Report, p. 24 (Computing Curricula, 2005)

\begin{tabular}{|c|c|c|c|c|c|c|c|c|c|c|}
\hline \multirow{2}{*}{ Knowledge Area } & \multicolumn{2}{|c|}{$C E$} & \multicolumn{2}{|c|}{ cs } & \multicolumn{2}{|c|}{ Is } & \multicolumn{2}{|c|}{ IT } & \multicolumn{2}{|c|}{$S E$} \\
\hline & $\min$ & $\max$ & $\min$ & $\max$ & $\min$ & $\max$ & $\min$ & $\max$ & $\min$ & $\max$ \\
\hline Programming Fundamentals & 4 & 4 & 4 & 5 & 2 & 4 & 2 & 4 & 5 & 5 \\
\hline Integrative Programming & 0 & 2 & 1 & 3 & 2 & 4 & 3 & 5 & 1 & 3 \\
\hline Algorithms and Complexity & 2 & 4 & 4 & 5 & 1 & 2 & 1 & 2 & 3 & 4 \\
\hline Computer Architecture and Organization & 5 & 5 & 2 & 4 & 1 & 2 & 1 & 2 & 2 & 4 \\
\hline Operating Systems Principles \& Design & 2 & 5 & 3 & 5 & 1 & 1 & 1 & 2 & 3 & 4 \\
\hline Operating Systems Configuration \& Use & 2 & 3 & 2 & 4 & 2 & 3 & 3 & 5 & 2 & 4 \\
\hline Net Centric Principles and Design & 1 & 3 & 2 & 4 & 1 & 3 & 3 & 4 & 2 & 4 \\
\hline Net Centric Use and configuration & 1 & 2 & 2 & 3 & 2 & 4 & 4 & 5 & 2 & 3 \\
\hline Platform technologies & 0 & 1 & 0 & 2 & 1 & 3 & 2 & 4 & 0 & 3 \\
\hline Theory of Programming Languages & 1 & 2 & 3 & 5 & 0 & 1 & 0 & 1 & 2 & 4 \\
\hline Human-Computer Interaction & 2 & 5 & 2 & 4 & 2 & 5 & 4 & 5 & 3 & 5 \\
\hline Graphics and Visualization & 1 & 3 & 1 & 5 & 1 & 1 & 0 & 1 & 1 & 3 \\
\hline Intelligent Systems (AI) & 1 & 3 & 2 & 5 & 1 & 1 & 0 & 0 & 0 & 0 \\
\hline Information Management (DB) Theory & 1 & 3 & 2 & 5 & 1 & 3 & 1 & 1 & 2 & 5 \\
\hline Information Management (DB) Practice & 1 & 2 & 1 & 4 & 4 & 5 & 3 & 4 & 1 & 4 \\
\hline Scientific computing (Numerical mthds) & 0 & 2 & 0 & 5 & 0 & 0 & 0 & 0 & 0 & 0 \\
\hline Legal / Professional / Ethics / Society & 2 & 5 & 2 & 4 & 2 & 5 & 2 & 4 & 2 & 5 \\
\hline Information Systems Development & 0 & 2 & 0 & 2 & 5 & 5 & 1 & 3 & 2 & 4 \\
\hline Analysis of Business Requirements & 0 & 1 & 0 & 1 & 5 & 5 & 1 & 2 & 1 & 3 \\
\hline E-business & 0 & 0 & 0 & 0 & 4 & 5 & 1 & 2 & 0 & 3 \\
\hline Analysis of Technical Requirements & 2 & 5 & 2 & 4 & 2 & 4 & 3 & 5 & 3 & 5 \\
\hline Engineering Foundations for SW & 1 & 2 & 1 & 2 & 1 & 1 & 0 & 0 & 2 & 5 \\
\hline Engineering Economics for SW & 1 & 3 & 0 & 1 & 1 & 2 & 0 & 1 & 2 & 3 \\
\hline Software Modeling and Analysis & 1 & 3 & 2 & 3 & 3 & 3 & 1 & 3 & 4 & 5 \\
\hline Software Design & 2 & 4 & 3 & 5 & 1 & 3 & 1 & 2 & 5 & 5 \\
\hline Software Verification and Validation & 1 & 3 & 1 & 2 & 1 & 2 & 1 & 2 & 4 & 5 \\
\hline Software Evolution (maintenance) & 1 & 3 & 1 & 1 & 1 & 2 & 1 & 2 & 2 & 4 \\
\hline Software Process & 1 & 1 & 1 & 2 & 1 & 2 & 1 & 1 & 2 & 5 \\
\hline Software Quality & 1 & 2 & 1 & 2 & 1 & 2 & 1 & 2 & 2 & 4 \\
\hline Comp Systems Engineering & 5 & 5 & 1 & 2 & 0 & 0 & 0 & 0 & 2 & 3 \\
\hline Digital logic & 5 & 5 & 2 & 3 & 1 & 1 & 1 & 1 & 0 & 3 \\
\hline Embedded Systems & 2 & 5 & 0 & 3 & 0 & 0 & 0 & 1 & 0 & 4 \\
\hline Distributed Systems & 3 & 5 & 1 & 3 & 2 & 4 & 1 & 3 & 2 & 4 \\
\hline Security: issues and principles & 2 & 3 & 1 & 4 & 2 & 3 & 1 & 3 & 1 & 3 \\
\hline Security: implementation and mgt & 1 & 2 & 1 & 3 & 1 & 3 & 3 & 5 & 1 & 3 \\
\hline Systems administration & 1 & 2 & 1 & 1 & 1 & 3 & 3 & 5 & 1 & 2 \\
\hline Management of Info Systems Org. & 0 & 0 & 0 & 0 & 3 & 5 & 0 & 0 & 0 & 0 \\
\hline Systems integration & 1 & 4 & 1 & 2 & 1 & 4 & 4 & 5 & 1 & 4 \\
\hline Digital media development & 0 & 2 & 0 & 1 & 1 & 2 & 3 & 5 & 0 & 1 \\
\hline Technical support & 0 & 1 & 0 & 1 & 1 & 3 & 5 & 5 & 0 & 1 \\
\hline
\end{tabular}

\section{Challenges Involved in Incorporating Ethical Aspects into the Computing Curricula}

\section{Early misconceptions about ethics}

The belief that computer ethics should not be a part of the computing curriculum (specifically the computer science curriculum at the time) was cited by Appel (1998) as a problem. This was ascribed to the belief that computer ethics was not considered part of conventional theoretical computer science. This belief was addressed in Appel (1998) and in the same year, Miller and Mather (1998) also confirmed that the social and technical elements of computing are interdependent.

\section{Teaching ethics by IT professionals considered inappropriate}

The requirements by ACM and mandates set by some governments on teaching of ethics and law in IT has generated serious challenges for technical and scientific academic staff untrained in humanities and who may not have a history of professional practice within the industry (Greening, Kay \& Kummerfeld, 2006). Greening et al. (2006) also identify other challenges relating to the integration of ethical content into technical units: empowerment of staff in teaching ethical content, engaging students with ethical issues, and mis-representation of the stuff by inexperienced staff. 


\section{Some Proposed Approaches to the Incorporation of Ethics into the Computing Curricula}

Greening et al. (2006) conclude that satisfying the ethical mandate does not require radical deviation from existing technical content. They argue for greater pooling of resources for staff to easily integrate ethical material into their teaching. Granger and Artz (1997) identified three approaches to the incorporation of ethics in the computing curriculum. Firstly, the inclusion of a dedicated course dealing with the subject. Secondly the inclusion of ethics as an important part of a capstone course at a senior level, and thirdly the allocation of ethical aspects across the computing curriculum. Pretorius, Barnard, and De Ridder (2002) adopted a hybrid approach consisting of integrated and stand-alone modules to incorporate ethics into the computing curriculum at UNISA (University of South Africa).

\section{Legislation governing computing in South Africa}

Literature details the association between ethics (or the apparent lack thereof) and legislation. In an effort to curb unethical behaviours, governments have introduced stringent legislations. This dates back to the 1930s when the Securities and Exchange Acts (USA) tried to curtail unethical business practices (Rockness \& Rockness, 2005). In South Africa, there are several legislations governing computing and other IT related practices. These are outlined below.

\section{Common law}

This is the law developed through decisions of courts rather than through statutes. Prior to the enactment of the Electronic Communications and Transactions Act (2002) in South Africa, common law regulated crimes of defamation, indecency (online child pornography), crimen injuria (also known as cyber-smearing), fraud (cyber fraud), defeating the ends of justice, contempt of court (in the form of publishing any court proceedings without the courts permission online or by other electronic means), and forgery to these cyber offences (Sizwe, 2009).

\section{The Electronic Communications \& Transactions (ECT) Act (2002)}

The ECT Act of 2002 is a wide legislation dealing with any form of electronic communication (e.g., by email, the internet, or SMS) and other issues relating to cyber inspectors, service provider liability, and prevention of information resource abuse (Michalson \& Hughes 2005). According to Michalson and Hughes (2005), one does not have to comply with the entire Act but with sections relating to incorporation by reference: electronic signatures, electronic evidence, production of information, record retention, automated transactions, website architecture and content, contract formation, cryptography service providers, secure payment systems, SPAM and protection of critical data.

The problems relating to cyber crime are addressed by the cyber crime section in Chapter XIII of the ECT Act, 2002. According to Michalson and Hughes (2005), this chapter introduces statutory criminal offenses relating to unauthorized access to data (e.g., through hacking), interception of data (e.g., tapping into data flows or denial of service attacks), interference with data (e.g., viruses) and computer related extortions, fraud, and forgery. They also state that a person aiding those involved in these crimes will be guilty as an accessory. A person convicted of an offence related to the above is liable to a fine or imprisonment for a period not exceeding five years.

\section{Protection of personal information}

The Act, for instance, requires that data controllers obtain express written permission from data subjects for collection, processing, or disclosure of their information. This Act makes its imperative for institutions to take necessary precautions in the way they handle and disclose personal 
information about students and staff. They have to ensure permissible uses and disclosure of information, and consent from information owners needs to be obtained in a manner that supports validity. Non-compliance with the provisions of this Act may result in criminal fines and award of civil damages (Michalson, 2009).

\section{HIPAA (The Healthcare Information Portability \& Accountability Act)}

This Act mandates that healthcare information become "portable" and "available”. Title II, Subtitle F, seeks to force uniform standards in electronic interchange, security, and privacy of information whether in transit or stored. HIPAA generally requires covered entities to (i) adopt written policy procedures that describe, among other things, who has access to protected information, how such information will be used, and when the information may be disclosed; (ii) require their business associates to protect the privacy of health information; (iii) train their employees in their privacy policies and procedures; (iv) take steps to protect against unauthorised disclosure of personal health records; and (v) designate an individual to be responsible for ensuring the procedures are followed. Educational institutions are obligated to comply with HIPAA.

\section{Promotion of Access to Information Act 2, 2000 (PAIA)}

This legislation was passed in order to comply with the obligations contained in section 9 (4) and section 32 (2) of the South African Constitution. Section 32 of the constitution of 1996 states that "everyone has the right of access to (a) any information held by the state or any of its organs ... in so far as such information is required for the exercise o protection of any of his or rights" (ArkoCobbah, 2008, p. 180). In terms of Sections 14 and 51 of the PAIA, public and private bodies are required to compile a manual that details the subjects and categories of information held by that public/private body and the procedure that should be adopted in requesting access to the records. Section 14(1)(d) of the Act allows access to the following records: Governance records (Council, Senate, Institutional Forum, SRC, Convocation and university Committees); Records of individual students; Human Resources records (individual staff members, staff recruitment and other staff related policies); Research records (undertaken by staff and/or students); Financial Records (budgets, financial statements, assets register, procurement policies).

\section{Regulation on Interception of Communication Related Information Act 70, 2002}

This Act provides in section 2 that no person may intentionally intercept or attempt to intercept, or authorise or procure any other person to intercept or attempt to intercept, at any place in the Republic, any communication in the course of its currency or transmission, subject to certain exceptions. An employer may monitor or intercept an employee's communication if the employee harbours illegitimate expectation of privacy in respect of that communication and also if the employee's expectation of privacy in relation to such communications is unreasonable. (see Cases : Bernstein v Bester 1996 (4) BCLR449 (CC) Protea Technology Ltd v Wainer 1997 (9) BCLR $1225(\mathrm{~W})$.

\section{King III (Code of Practice)}

King III identified several characteristics of good Corporate Governance, e.g., discipline, transparency, independence, accountability, responsibility, fairness, and social responsibility. It addresses the accountability and responsibilities of boards and directors and the processes of auditing and accounting. Chapter 4, principle 4.16 addresses IT governance issues. According to this section, the board is required to operate with IT governance in mind; IT should be on the board agenda; IT performance should be measured and reported to the board; the board should set a 
management framework for IT governance based on common approach such as COBIT; and audit committees should oversee IT risks and controls.

\section{FICA (Financial Intelligence Centre Act)}

This Act provides that an accountable institution may not conclude a business transaction with a client, nor establish an ongoing business relationship with a client, without having complied with information gathering and reporting duties imposed by FICA. These obligations include: Proof of identity, Proof of residential address, and Proof of banking account. Universities are increasingly involved in e-business, e-commerce (e.g., with suppliers through e-procurement) and e-learning. They therefore need to abide by the requirements of FICA.

\section{Challenges involved in incorporating legal aspects into the computing curricula}

Recent technological advances indicate that the IT field is dynamic and, therefore, that law governing IT is continually changing and evolving. Therefore, aspects of IT law are broad (from multimedia, computer games, e-commerce, security, computer forensics, etc). There is, therefore, likely to be varying aims and objectives and law requirements (Taylor, Jones, Haggerty, \& Gresty, 2009). Consideration need to be given to what is relevant for the intended course.

Other scholars (e.g., Byles \& Soetendorp, 2002; Morris, 2007) have identified the challenges of teaching law to students whose main discipline is not law. They raise issues relating to the pedagogical approach, content of the course, the needs of the learners, their interests and attitudes, who should or not teach them, and research-related issues.

\section{Suggested Approaches to Addressing this Problem}

In their work on teaching law to social work education, Braye, Preston-Shoot, and Johns (2006) provide guidance on how this problem may be addressed. They, for instance, argue that the aim should not be to create legal experts but "to provide a legal education that enables students to operate effectively in their environment using legal concepts and rules and that ensures that they have a thorough knowledge of their profession, relevant legal rules and the relationship between them” (p.139). This view is supported by Byles and Soetendorp (2002). Braye et al. (2006) further stated that while the debate on who should teach legal aspects rages on (i.e., lawyers or not), who ever is involved should carefully prepare the topics, avoid communicating erroneous stereotypes and have adequate understanding of the relevance of the discipline they are working in. In the same vein, teaching and learning should also be aligned by not just covering specific legal rules but place them in the context of decisions that students, as practitioners will be expected to take (Braye et al., 2006). Such alignment should also be reflected in the assessment.

\section{Research Questions}

The research questions considered in the present study are:

What approaches to computing curricula development have South African (SA) institutions adopted?

What factors have influenced the development of computing curricula in SA institutions?

Have legal and ethical aspects been integrated into the current computing curricula effectively? 


\section{Research Design}

Multiple methods were used to collect data in the present study. Secondary data was collected from existing published legislation governing use of IT. This was done in order to identify the key legal and ethical aspects of the regulation that need to be integrated into the curriculum. We also needed to understand the contents of existing courses and some of the policies documented by the institutions on legal and ethical aspects. This was partly achieved by examining the handbooks and other materials in the departments. Primary data was then collected using a survey instrument hosted online, and follow-up interviews were done telephonically with those respondents that indicated willingness to participate. The online survey questions were developed from the key areas and concepts identified from the literature review and from the ACM computing curricula (CC2005) framework. For questions that required a response based on a view or an opinion, a five point Likert-style rating scale was used. The survey collected information on profiles of the respondents, existing computing curricula and how it was developed, integration of legal and ethical aspects, and whether respondents were willing to participate in further interviews.

The target population was key academic staff members in computing departments at selected tertiary institutions. Institutions that offer computing curricula in South Africa are known to the researchers as well as some of the academics and heads of departments. An email requesting participation in the study was sent out to 6 heads of department and their staff members. Three institutions responded, and the participants included: course conveners that were involved in the compilation of the computing curricula; researchers in this area; and lecturers teaching the computing courses. Judgemental sampling technique was therefore used to select the sample since our focus was to include those academic staff involved in computing.

The survey was hosted on http://www.surveymonkey.com and a hyperlink to this site was contained in an introductory email that was sent to the sampled population. Those survey respondents that opted for the follow-up interviews were contacted for this. The interviews were recorded with an electronic audio recorder and transcripts were made from these recordings. The duration of interviews, ranged from approximately 15 to 30 minutes.

Secondary data sources used included the key legislations governing the use of IT in South Africa (outlined in the literature review) and faculty handbooks for the faculty of commerce (University of Cape Town 2008-2010); Faculty of Commerce, Law and Management (University of Witwatersrand 2010); and Faculty of Management (University of Kwazulu-Natal 2010). We looked for evidence of legal and ethical aspects covered in the key legislations that was listed in the course outlines. The analysis of data and findings are presented in the sections below.

\section{Analysis of Data and Findings}

\section{Profile}

17 responses were received in all. 2 hold Honours degrees, 5 hold Masters degrees, 10 hold PhDs. 11 of these respondents have more than 9 years of education experience in the computing field, 2 have 7-9 years experience, 3 have 3-5 years experience and 1 has less than 3 years experience. These respondents consisted of 8 Lecturers, 5 Heads of departments, 2 Associate Professors and 2 Research assistants (PhD candidates). Of the senior academics 3 were Course conveners, 4 Postgraduate mentors. Most of the respondents were involved in more than one computing disciplines. For instance, 15 indicated that they were involved in the Information systems discipline, 2 in computer science, 4 in Information technology, 3 in Software Engineering , 1 in informatics, 2 in electronic engineering, 3 in information strategy and 4 in information management. (The 
names of the respondents quoted in this paper are withheld for confidentiality purposes. These are referred to as L, e.g., L1, L2, L3, etc).

\section{Approaches to computing curricula development}

Respondents were asked to indicate the type of computing curricula model used by their departments and results are presented below.

\begin{tabular}{l|c} 
Model types & $\begin{array}{c}\text { Response } \\
\text { Count }\end{array}$ \\
\hline ACM Model Curricula (used as-is) & 1 \\
Model curricula adapted from ACM & 1 \\
Hybrid Model derived from multiple sources, ACM \& others & 4 \\
Our model developed 'in-house' & 1 \\
Unknown & 8
\end{tabular}

Four of the seven respondents that knew the models used by their departments indicated a hybrid type of model. In addition, respondents were also asked for their opinion about the usefulness of the ACM model as a reference for computing curricula development. 5 respondents found the ACM model useful, one disagreed and the rest did not know. We found that most of those who did not know were not really involved in the initial processes of curricula development.

The ACM model has proved to be a useful reference for computing curricula development.

Answer Options

Strongly agree

Agree

Do not know

Disagree

Strongly disagree
Response Count

2

3

9

1

0

\section{Factors influencing computing curricula development}

Three questions were asked to determine some of the factors influencing curricula development, i.e., policies, existing models and regulations, and experience of staff members. The results below indicate that most influences on the computing curricula development in most institutions were the department policy, ACM guidelines and Faculty Policy. It is surprising to find that the requirements of SAQA (South African Qualifications Authority - the body that approves qualifications in South Africa), were not perceived to have much influence on computing curricula development. This is partly correct for SAQA requirements do not stipulate much on such integration (to the authors' knowledge). Other influencing factors identified in a few institutions were industry requirements, AIS and IEEE guidelines, etc. These were mainly raised by institutions that network with international organisations and those engaged in software engineering where professional practices are emphasised. 


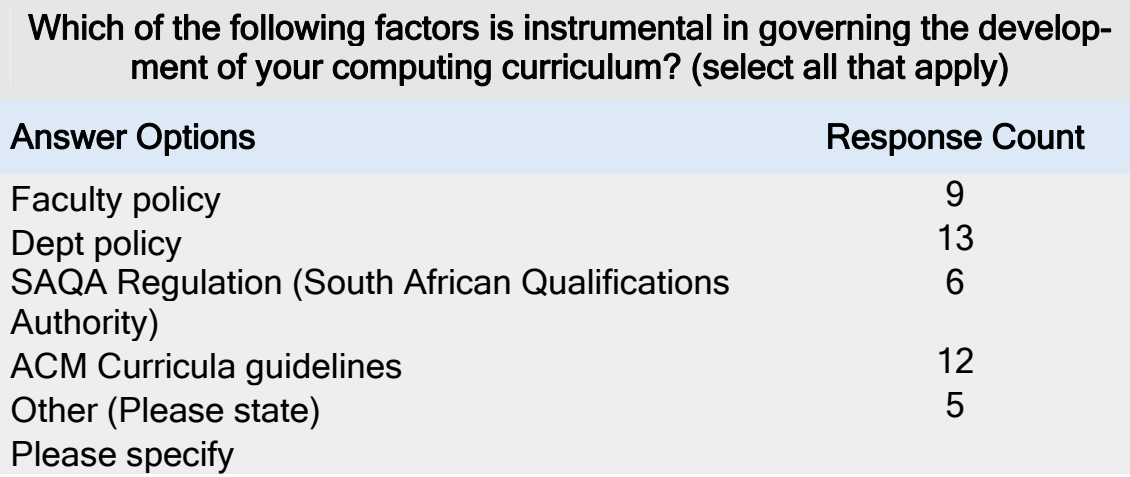

Others specified: AIS and IEEE Curriculum guidelines; ABET Accreditation; Industry requirements; Expertise of lecturing staff.

We also determined the level of knowledge respondents possessed on the legislation that govern computing and IT-related aspects.

\begin{tabular}{|c|c|c|c|c|c|c|}
\hline \multicolumn{7}{|c|}{ For the following please indicate your level of knowledge in each case } \\
\hline \multicolumn{7}{|c|}{ Level of Knowledge } \\
\hline Answer Options & $\begin{array}{c}\text { In depth } \\
\text { knowledge } \\
\text { of all facets }\end{array}$ & $\begin{array}{c}\text { A good } \\
\text { understanding, } \\
\text { able to convey } \\
\text { the main aspects } \\
\text { and concepts }\end{array}$ & $\begin{array}{c}\text { Have a } \\
\text { basic } \\
\text { under- } \\
\text { standing of }\end{array}$ & $\begin{array}{c}\text { Awareness } \\
\text { only }\end{array}$ & $\begin{array}{c}\text { No prior } \\
\text { aware- } \\
\text { ness }\end{array}$ & $\begin{array}{c}\text { Response } \\
\text { Count }\end{array}$ \\
\hline $\begin{array}{l}\text { ECT (Electronic commu- } \\
\text { nications and Transac- } \\
\text { tions) Act }\end{array}$ & 0 & 7 & 3 & 4 & 1 & 15 \\
\hline $\begin{array}{l}\text { Protection of personal in- } \\
\text { formation bill }\end{array}$ & 0 & 3 & 4 & 7 & 1 & 15 \\
\hline SOX (Sarbanes Oxley) & 1 & 0 & 4 & 8 & 2 & 15 \\
\hline $\begin{array}{l}\text { RICA (Regulation of inter } \\
\text { ception of Communica- } \\
\text { tions and Provision of } \\
\text { Communication Related } \\
\text { Information) Act }\end{array}$ & 0 & 4 & 2 & 8 & 1 & 15 \\
\hline $\begin{array}{l}\text { PAIA (Promotion of Ac- } \\
\text { cess to Information) Act }\end{array}$ & 0 & 2 & 1 & 8 & 4 & 15 \\
\hline
\end{tabular}

The ECT Act (which addresses ethical and legal issues involved in the use of electronics) had the highest number of responses compared to other cases. This indicates that there is a good level of understanding of the ECT Act with respect to others.

The level of knowledge for RICA and the PAIA Acts are relatively low, given that most of the responses fall within the three options that range from a basic understanding to finally no prior awareness thereof. The responses for the Protection of Personal Information Bill are also relatively low, where 12 out of the 15 responses, fall within a basic understanding or lower. Most of these 12 responses are associated to 'Awareness only'. Given that the indicated levels of knowledge for these pieces of South African legislation (i.e., ECT, RICA, PAIA and the Protection of 
Personal Information Bill) are relatively low in terms of the ability to convey the main aspects thereof; this is a point of concern that is noted for further discussion.

Respondents with education experience were then directed to the question that asked for the number of years they have been teaching legal and ethical aspects. 3 had a relatively low level of experience, i.e., ' 1 to 3 ' years, 2 indicated ' 3 to 5' years and only one indicated 5-7 years of experience.

\section{Legal and ethical aspects of the current legislation integrated in computing curricula}

Respondents were also requested to indicate the proportion of legal and ethical aspects in their courses.

\begin{tabular}{l|c|}
\multicolumn{2}{|c|}{$\begin{array}{c}\text { What proportion of legal and ethical aspects } \\
\text { makes up your computing curricula? }\end{array}$} \\
$\begin{array}{l}\text { Response } \\
\text { Count }\end{array}$ \\
Answer Options & 0 \\
The majority of it (over $75 \%)$ & 0 \\
A significant proportion (up to 50\%) & 1 \\
A third (up to $33.3 \%)$ & 12 \\
Not significant (10\%, or less) & 2 \\
None
\end{tabular}

Of the 15 respondents that answered this question, 14 indicated that the proportion of legal content in their computing course was either 'Not significant at (10\%, or less)' or 'None'. As this question requested their 'best estimate', it reflects a view that the amount of such content is not a significant amount compared to other course content.

Further, respondents were also requested to indicate legal and ethical aspects integrated in their courses

\section{Please indicate the legal and ethical aspects integrated in your course: \\ (select all that apply)}

\section{Answer Options}

ICT and Telecommunication Laws (including topics on cyber-crime and other unethical practices)

Criminal Law \& Principles

Intellectual Property Law and related protections and rights, e.g. Trade marks, Patents, Copyright

Commercial Law relating to trade and contracts

Freedom of expression \& related areas of defamation, obscenity and indecency

Other (please specify)

Financial Services Act
Response

Count

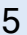




\section{Responsiveness of the curriculum to changes}

The responsiveness of the curriculum particularly to the non-technological developments is mostly considered to be moderate (7 out of 14 respondents that answered this question felt that it was moderately responsive). We found that 11 out of the 14 responses conducted formal review of the curricula every two years. Most respondents (10 out of 14 that answered the question) also felt that the curricula were moderately responsive to other non-technological developments (e.g., social, ethical, and legal).

To what extent is your curriculum responsive to new technological developments?

\section{Answer Options}

Higher responsive Very responsive Moderately responsive Low level - only in some instances Not Responsive
Response Count

1

5

7

2

0

To what extent is your curriculum responsive to other nontechnological developments (e.g., ethical and other issues)?

\section{Answer Options}

Higher responsive

Very responsive

Moderately responsive

Low level - hardly ever

Not Responsive
Response Count

1 1 10

2

0

\section{Legal and ethical aspects in published computing curricula}

As indicated above, the university handbooks were reviewed for instances of content related to ethical, legal or professional aspects. The data collected is shown in the following tables:

Table 2.1: UCT Handbooks - 2008

\begin{tabular}{|c|c|c|c|c|}
\hline $\begin{array}{c}\text { University } \\
\text { Handbook, } \\
\text { Year }\end{array}$ & Faculty & Department & $\begin{array}{c}\text { Course Description, } \\
\text { Code }\end{array}$ & Reference, page \\
\hline UCT 2008 & Commerce & IS & $\begin{array}{c}\text { Information Systems I, } \\
\text { INF1002F/S/H }\end{array}$ & $\begin{array}{c}\text { "The nature and value of in- } \\
\text { formation as well as the impact } \\
\text { of Internet technology on or- } \\
\text { ganisations and society are also } \\
\text { considered”, p 138 }\end{array}$ \\
\hline UCT 2008 & Commerce & IS & $\begin{array}{c}\text { Electronic Commerce, } \\
\text { INF3014F }\end{array}$ & $\begin{array}{c}\text { "legal and ethical issues”, } \\
\text { p 142 }\end{array}$ \\
\hline UCT 2008 & Commerce & $\begin{array}{c}\text { Computer } \\
\text { Science }\end{array}$ & $\begin{array}{c}\text { Computer Science, } \\
\text { CSC1016S }\end{array}$ & $\begin{array}{c}\text { “Ethics and professional issues } \\
\text { in computing”, p 211 }\end{array}$ \\
\hline
\end{tabular}


Table 2.2: UCT handbooks -2009

\begin{tabular}{|c|c|c|c|c|}
\hline $\begin{array}{c}\text { University Hand- } \\
\text { book, } \\
\text { Year } \\
\end{array}$ & Faculty & Department & $\begin{array}{c}\text { Course Description, } \\
\text { Code }\end{array}$ & Reference, page \\
\hline UCT 2009 & Commerce & IS & $\begin{array}{c}\text { Information Systems I, } \\
\text { INF1002F/S/H }\end{array}$ & $\begin{array}{c}\text { "The nature and value of infor- } \\
\text { mation as well as the impact of } \\
\text { Internet technology on organisa- } \\
\text { tions and society are also consid- } \\
\text { ered", p } 144\end{array}$ \\
\hline UCT 2009 & Commerce & IS & $\begin{array}{l}\text { Establishing an E- } \\
\text { Business, INF2005F } \\
\text { (offered from 2010) }\end{array}$ & “legal issues”, p 145 \\
\hline UCT 2009 & Commerce & IS & $\begin{array}{c}\text { Electronic Commerce, } \\
\text { INF3014F }\end{array}$ & $\begin{array}{c}\text { "legal and ethical issues", } \\
\text { p } 148\end{array}$ \\
\hline UCT 2009 & Commerce $^{1}$ & $\begin{array}{l}\text { Computer } \\
\text { Science }\end{array}$ & $\begin{array}{l}\text { Computer Science, } \\
\text { CSC1016S }\end{array}$ & $\begin{array}{c}\text { "Ethics and professional issues in } \\
\text { computing", p } 216\end{array}$ \\
\hline
\end{tabular}

Table 2.3: Sampled computing curricula - 2010

\begin{tabular}{|c|c|c|c|c|}
\hline \begin{tabular}{|} 
University Hand- \\
book, \\
Year
\end{tabular} & Faculty & Department & $\begin{array}{l}\text { Course Description, } \\
\text { Code }\end{array}$ & Reference, page \\
\hline UCT 2010 & Commerce & IS & \begin{tabular}{|} 
Information Systems I, \\
INF1002F/S/H
\end{tabular} & $\begin{array}{l}\text { "The nature and value of } \\
\text { information as well as the } \\
\text { impact of Internet technol- } \\
\text { ogy on organisations and } \\
\text { society are also considered", } \\
\text { p } 171\end{array}$ \\
\hline UCT 2010 & Commerce & IS & $\begin{array}{c}\text { Electronic Commerce, } \\
\text { INF3014F }\end{array}$ & $\begin{array}{c}\text { "legal and ethical issues", } \\
\text { p } 175\end{array}$ \\
\hline UCT 2010 & Commerce $^{1}$ & $\begin{array}{l}\text { Computer Sci- } \\
\text { ence }\end{array}$ & $\begin{array}{l}\text { Computer Science, } \\
\text { CSC1016S }\end{array}$ & $\begin{array}{c}\text { "Ethics and professional } \\
\text { issues in computing", p } 264\end{array}$ \\
\hline Wits $2010^{2}$ & Commerce $^{2}$ & IS & $\begin{array}{l}\text { Information Systems } \\
\text { III, INFO3000 }\end{array}$ & “IS professionalism”, p 224 \\
\hline Wits $2010^{2}$ & Commerce $^{2}$ & IS & \begin{tabular}{|l|} 
Management and Ap- \\
plication of Information \\
Systems III, INFO3002 \\
\end{tabular} & $\begin{array}{c}\text { "IS professionalism”, p } 224 \\
\text { "The course is comprised of } \\
6 \text { topics: (6) Ethical, social } \\
\text { and legal issues in IT.”, } \\
\text { p } 224\end{array}$ \\
\hline UKZN $2010^{3}$ & $\begin{array}{c}\text { Management } \\
\text { Studies }\end{array}$ & $\begin{array}{l}\text { School of In- } \\
\text { formation Sys- } \\
\text { tems \& Tech- } \\
\text { nology }\end{array}$ & $\begin{array}{l}\text { IS \& T for Business, } \\
\text { ISTN101 W1 P1 }\end{array}$ & $\begin{array}{c}\text { "societal and ethical issues } \\
\text { relating to IS \& T use", } \\
\text { p } 196\end{array}$ \\
\hline
\end{tabular}


Notes:

1. Faculties and departments offering courses to the faculty of commerce.

2. "Degrees and Diplomas in Commerce, Law and Management”, University of the Witwatersrand, Johannesburg 2010

3. "Faculty of Management Studies, in the College of Law and Management Studies Pietermaritzburg Westville Campus, Handbook for 2010”, University of KwaZulu-Natal 2010

\section{Discussion of Findings}

This section discusses the findings of the survey. Data collected from the interviews is also used to corroborate these findings.

\section{Curricula Development}

\section{Models of computing curricula adopted}

The primary survey data indicated that curriculum development models existed, as 7 out of the 15 respondents that answered this question indicated that they used some models in their development. Most used hybrid models derived from multiple sources (i.e., ACM and others). They felt that ACM is largely American and needed to be tailored for the needs of the South Africa communities. This is strongly supported by Brewer, Harriger, and Mendonca (2006), who maintain that a model curriculum used as a reference should be tailored for the needs of the particular program under construction. While the reference models were found to be useful to some extent, respondents were concerned about their infrequent update.

\section{Factors influencing curriculum development}

A number of internal and external factors influence the process of curriculum development. The choice of the reference model and the realisation of the need to develop curricula from multiple models (hybrid model) were most likely informed by the level of understanding of the requirements for the undergraduate courses. Most respondents were highly qualified senior academics with 9 years and over of computing experience and as such understood the requirements of their courses. Institutions that organised annual strategic meeting to examine their entire undergraduate curricula had more structured processes for curriculum development.

In addition, the department policy was identified to be the most instrumental influence: more than other sources like faculty policy and ACM curricula guidelines. Academic disciplines usually have assumptions and principles which tend to be emphasised more in the curricula than other external requirements (Hammond \& Bennett, 2002). Barnard, De Ridder, Pretorious, and Cohen (2003) also confirm that departmental pragmatics and logistics can have a major influence on the approach adopted for the curricula development. Participant (L4) in the present study stated that:

"my primary responsibility is one of academic leadership underneath that falls the requirement to ensure that the curriculum is industry relevant and aligned to the expectations of various associations like AIS and IEEE”.

Another related influence raised during the interviews was the identity of the faculty. Some respondents questioned whether their current classifications were really appropriate i.e., “...not totally computing as technology was located in the management faculty (L2). This in a way created some challenges as to which aspects to include or not in the curricula. 


\section{Integration of Legal and Ethical Aspects}

\section{Content}

The content of the curricula identified in the secondary materials and in the survey were ethics and professional issues in computing, IS professionals, ICT \& telecommunication laws (including topics on cyber-crime and other unethical practices), intellectual property, copyright, and commercial law aspects. Respondents also identified the following during the interviews: copyright (identified by participant L1); e-commerce (L1); privacy, property, accountability (L4); professionalism, social, ethical issues; freedom of expression (L2); cyber security legislation, international law (L2). Most respondents (12 out of 15) felt, however, that the content of their courses are still deficient in legal and ethical aspects and were unstructured. This is also confirmed by the fact that only 5 respondents had integrated ICT and telecommunication legal and ethical aspects into their curricula. This deficiency can be explained by a number of challenges involved in the process of incorporation identified below.

\section{Challenges of incorporation}

A number of challenges to the incorporation of legal and ethical aspects into the curricula were raised in the survey and the interviews. While there appears to be a good understanding of the ECT Act and the implications for non-compliance, most participants possessed limited knowledge of other legislations like PPI, RICA, and PAIA Acts. For example, 12 out of 15 participant lacked knowledge of the Protection of Personal Information Bill. Such low level of understanding explains the limited content on legal and ethical aspects. Participant L1 attributes this deficiency on a lack of proper training and knowledge:

So I think that there needs to be some sort of like training on the legal issues ...... the second thing is the lack of knowledge, generally with IS departments there are not many people with legal skills .......we were fortunate to have a legal graduate in our department who just retired last year, so he would cover some of these aspects in his the ecommerce module, but that's because he did law, he studied law and he was a graduate so you know he knew the legal aspects, none of us have had it as part of our, you know, studies. (L1)

The problem of the local content deficiency in the curricula) was also raised whereby participants felt that the content was not properly contextualised (had limited South African context).

In my e-commerce module this semester I do have a chapter in the textbook which deals with ethical and legal issues, but once again all the material there is American based...So what I've done is that, I've given them an assignment to look up legal, the legal issues in the South African context based on ecommerce. (L1)

In their study on teaching law to non-lawyers (i.e., social workers), Braye et al. (2006) emphasise the need to create a balance of what each discipline should offer (level of disciplinary exchange desirable). They also state that such a balance can be achieved through joint teaching and tutoring and use of case studies. They recommend that student learning should be focused on context as much as on content to ensure appreciation of how legal rules might impact and support their decision making. They caution that too much focus on content isolate the legal rules and may promote surface learning.

Another issue relates to the resistance to change. Participant L2 stated that there was some sort of apathy where staff members were not familiar with the topics. Further probing during the interviews revealed that there was fear of change and added workload. There were concerns, for instance, that the curricula already covered many other aspects and could not accommodate additional concepts. Morris (2007) argues that some consideration need to be given to the fact that 
professional knowledge, teaching habits, and paradigms may resist substantial restructuring of curriculum. Braye et al. (2006) also observed similar feelings of apprehension about the law among the teachers and students. They recommend that learning must engage with students' assumptive worlds, perceptions and anxieties about the laws.

The findings and discussion above provide the following answers to the research questions:

Which models of computing curricula have SA institutions adopted and why? Are these models useful?

While respondents appear to find models like ACM useful as a point of departure, given their limitations (e.g., in terms of currency) and the need to integrate departmental and national context, many of the institutions have adopted hybrid models drawn from multiple sources.

What factors have influenced the development of computing curricula in South African institutions?

There are Internal and external factors influencing the process of developing the computing curricula. These range from the nature of the discipline, the historic aspect of the institutions and departments, availability of skills and resources, and attitude to change.

Have legal and ethical aspects been integrated into the current computing curricula effectively?

To some extent, some legal and ethical aspects have been integrated but respondents felt they were not sufficient and not properly structured in some cases. This might have made the process of integration difficult for some departments.

\section{Conclusion and Recommendations}

The objective of this study was to investigate the extent to which legal and ethical issues pertinent to computing are integrated in the undergraduate curricula in South African Universities and also to identify some of the challenges experienced by institutions in this process.

The findings and the discussion in the previous sections indicates that while some effort has been made to integrate these aspects, these aspects are still deficient in the curricula of the institutions involved in this study. Success in this integration depends on better understanding of the purpose of the integration, perceptions of the academics and learners, and disciplinary issues. This knowledge can be gained through appropriate training and collaboration with the faculty of law on legal issues. The study also shows that curricula development in these institutions is mainly influenced by the department policies. While this is probably due to the historic development of the departments, curricula have to integrate international and industry and should be tailored for the local needs to ensure relevance. There is also a need to alleviate fears among academics regarding changes introduced by such developments. Continuous review of the developed curricula is crucial as new development in technology and in the legislative environment take place (Brewer et al., 2006).

This study did not examine the methods adopted by institutions in teaching, learning, and assessment of the ethical and legal aspects of computing. These too could have an impact on the development of the curricula. There is also limited research on integration of these aspects into the South Africa context. Existing literature is mainly descriptive and conceptual rather than empirical. These issues need to be investigated further in future studies. 


\section{References}

ACM/IEEE-CS Joint Curriculum Task Force in Computing Curricula. (1991). ACM/IEEE-CS Joint Curriculum Task Force Report. NY: ACM Press.

Appel, F. (1998). Including the social and ethical implications of computing in the computer science curriculum, Computers and Society, 28(2), 56-57.

Arko-Cobbah, A. (2008). The right of access to information: Opportunities and challenges for civil society and good governance in South Africa. IFLA Journal. Retrieved 10 August, 2011 from http://ifl.sagepub.com

Artz, J. M. (1994). Virtue vs. utility: Alternative foundations for computer ethics. Proceedings of the Conference on Ethics in the Computer Age, pp 16-21

Baase, S. (1997). A gift of fire: Social, legal, and ethical issues in computing. Upper Saddle River, NJ: Prentice Hall.

Baase, S. (2007). A gift of fire: Social, legal, and ethical issues for compuing and the internet (3rd ed.). Upper Saddle River, New Jersey: Pearson / Prentice Hall.

Barnard, A., De Ridder, C., Pretorious, L., \& Cohen, E. (2003). Integrating computer ethics into the computing curriculum. A framework for implementation. Proceedings of the Informing Science and IT Education ( $I^{n}$ SITE) Conference, June 2003. Retrieved from http://proceedings.informingscience.org/IS2003Proceedings/docs/043Barna.pdf

Bogoiavlenski, I. A., Clear, A. G., Davies, G., Flack, H., Myers, J. P., \& Richard, R. (1997). Historical perspectives on the computing curriculum. [ITiCSE '97 working group papers]. ACM SIGCUE Outlook Archive, 25(4), 94-111.

Braye, S., Preston-Shoot, M., \& Johns, R. (2006). Lost in translation? Teaching law to non-lawyers: Reviewing the evidence from social work. The Law Teacher, 40(2), 131-150.

Brewer, J., Harriger, A., \& Mendonca, J. (2006). Beyond the model: Building an effective and dynamic IT curriculum. Journal of Information Technology Education, 5, 441-458. Retrieved from http://www.jite.org/documents/Vol5/v5p441-458Brewer149.pdf

Byles, L., \& Soetendorp, R. (2002). Law teaching for other programmes, In R. Burridge, K. Hinett, A. Paliwala, \& T. Varnava (Eds), Effective learning and teaching in law, (pp.144-163) London: Kogan Page.

Computing Curricula. (2005). The Overview Report. Retrieved March 01, 2011, from http://www.acm.org/education/curric_vols/CC2005-March06Final.pdf

Conger, S., \& Loch, K. D. (1995). Ethics and computer use. Communications of the ACM, 38(12), 30-32

Cragg, W. (1997). Teaching business ethics: The role of ethics in business and in business education. Journal of Business Ethics, 16, 231-245.

Dillon, A. (2004). Education in Plato's Republic. Retrieved February 18, 2010, from http://www.scu.edu/ethics/publications/submitted/dillon/education_plato_republic.ht

Finkelberz, M. (2002). Virtue and circumstances: On the city-state concept of Arete. American Journal of Philosophy, 123(1), 35-49.

Granger, M. J., \& Artz, J. M. (1997). Computer ethics: Some pedagogical approaches. International Business Schools Quarterly, 8(3), 8-14.

Greening, T., Kay, J., \& Kummerfield, B. (2006). Integrating ethical content into computing curricula. Retrieved February 20, 2009, from www.acs.org.au/documents/public/crpit/CRPITV30Greening.pdf

Hammond, N., \& Bennett, C. (2002). Discipline differences in role and use of ICT to support group based learning. Computer Assisted Learning Journal, 18(1), 55-63. 
Kyobe, M. E., Palesa, M., \& Salie, T. (2009). Investigating electronic records management and compliance with regulatory requirements in a South African university. South African Journal of Information Management, 11(1), 1-16.

Martin, C. D., \& Yale-Weltz, E. (1999). From awareness to action: Integrating ethics and social responsibility into the computer science curriculum. Computers and Society, 29(2), 6-13.

Michalson, L. (2009). Protection of Personal Information Bill - The implications for you. Retrieved December 02, 2009, from http://www.michalsons.com/protection-of-personal-information-bill-theimplications-for-you/3041

Michalson, L., \& Hughes, B. (2005). Guide to the ECT Act, Michalsons Attorneys. Retrieved September 20, 2006, from http://www.michalson.com

Miller, H., \& Mather, R. (1998). The presentation of self in WWW home pages. Paper presented at the annual meeting of Internet Research and Information for Social Scientists (IRISS '98) Conference, Bristol, UK. [Online] Available: http://www.sosig.ac.uk/iriss/articles/article21.htm

Moor, J. H. (1985). What is computer ethics? In T. W. Bynum (Ed.), Computers and ethics. (pp. 266-275). New York: Blackwell.

Morris, R. (2007). Improving curriculum theory and design for teaching law to non-lawyers in built environment education. Structural Survey, 25(3/4), 279-292.

Pretorius, L., Barnard, A., \& De Ridder, C. (2002). Introducing computer ethics into the computing curriculum: Two very different experiments. SACLA 2002 Conference Proceedings, East London, June 27-29

Reid, I., A. (1999). Beyond models: Developing a university strategy for online instruction, Journal of Asynchronous Learning Networks, 3(1), 19-31.

Rockness, H., \& Rockness, J. (2005). Legislated ethics: From Enron to Sarbanes-Oxley, the impact on corporate America. Journal of Business Ethics, 57(1), 31-54.

Scott, D. (2006). Plato's Meno. London: Cambridge University Press.

Sizwe, S. S. (2009). Cyber crime in South Africa - Hacking, cracking, and other unlawful online activities. Journal of Information, Law and Technology. Retrieved December 2011, from http://www.thefreelibrary.com/Cyber+crime+in+South+Africa++hacking,+cracking,+and+other+unlawful...-a0206342917

Sutirtha, C. (2005). A model of unethical usage of information technology. AMCIS 2005 Proceedings. Paper 51, AIS Electronic Library (AISEL) [Online] Available at http://aisel.aisnet.org/amcis2005/51

Taylor, M., Jones, R., Haggerty, J. \& Gresty, D. (2009). Teaching information technology law. Journal of Further and Higher Education, 33(4), 473-481.

Tucker, A. B., Barnes, B. H., Aiken, R. M., Barker, K., \& Bruce, K. (1991). Report of the ACM/IEEE-CS joint curriculum task force report: Computing curricula 1991.

Urmson, O. J. (1991). Aristotle ethics. Wiley-Blackwell. 


\section{Biographies}

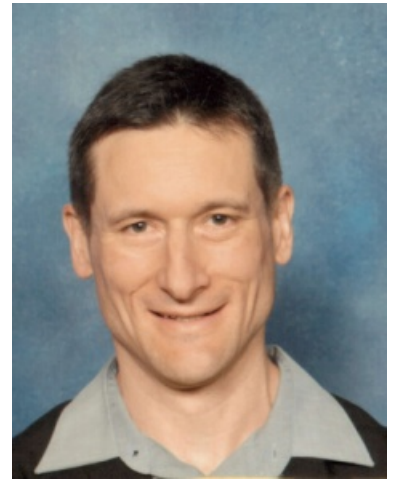

Ian Wayman has been involved in the Information System (IS) field since the mid 1990's. He initially worked in the banking and retail sectors and from late 1999 until 2010 he worked on various IS consulting projects that included the telecommunications sector. During this time he gained mostly self-taught knowledge ranging from hardware to operating systems, networking and databases along with much troubleshooting experience. Prior to entering UCT in 2009 he obtained a Diploma in Datametrics from UNISA. At UCT he completed a year of post-graduate study in business process management and in 2010 received his honours degree. His honours research topic was on the incorporation of legislation into the computing curriculum. He is currently involved in different business ventures, one of which deals with web development and search engine optimisation.

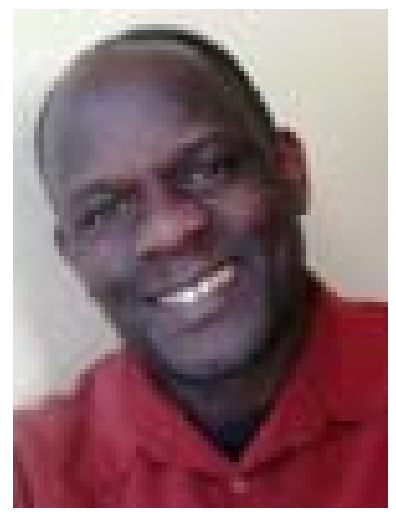

Michael Kyobe is A/Professor of Information System. He holds a PhD in Computer Information Systems and a Masters Degree in Business Administration. He teaches strategic planning \& management, IT and Corporate governance, Information system evaluation, and internal controls. Michael worked as a project manager and IT manager for several years and has consulted extensively with the public, medium and small sized firms in the above fields. His research interests include strategic planning, business-IT alignment, computer security and ethics and knowledge management. 